\title{
PENGUATAN KAPASITAS KELEMBAGAAN PEMERINTAH DAERAH SEBAGAI AGENDA UTAMA OPTIMASI PENGELOLAAN DAERAH PERBATASAN
}

\author{
Oleh: Haris Faozan ${ }^{3}$
}

\begin{abstract}
Matters related with regional borders have become part of the core issues of Indonesian incumbent-government. The government efforts to deal with the developing issues haves continuously been made. There are at least two fundamental matters that have drawn the attention of government, i.e. physically determination of state borders and the management of territorial borders development. In relation to the latter, it is a right time for the government to not only studying but also initiating a specific government institution that will be in charge of managing the potencies and complexities of the territorial borders. At present it is deemed necessary for the central government to facilitate the establishment of such institution to promote the development of border areas. Therefore, this is an important agenda that should be carried out soon. Moreover, local governments along the border areas, in general, require support and facilitation from the central government in developing their region.
\end{abstract}

Keywords: kapasitas kelembagaan, daerah perbatasan.

\section{Latar Belakang}

Suatu negara pada umumnya berbatasan langsung dengan negara tetangganya, baik di wilayah darat, laut, maupun udara. Indonesia sebagai negara kepulauan termasuk negara yang memiliki perbatasan negara di ketiga wilayah tersebut. Secara geografis Indonesia berbatasan langsung dengan 10 negara yaitu Malaysia, Papua Nugini (PNG), Timor Leste, Australia, India, Thailand, Singapura, Vietnam, Palau, dan Filipina. Wilayah-wilayah perbatasan Indonesia, termasuk pulau-pulau kecil terluar merupakan wilayah terpencil dan kondisinya masih tertinggal atau terbelakang.

Permasalahan yang eksis di wilayah-wilayah perbatasan dapat dikatakan rumit dan membutuhkan ekstra perhatian dari Pemerintah Pusat maupun Daerah dan bahkan pihakpihak dunia usaha. Hal ini dikarenakan selain terkait dengan permasalahan keamanan, ketertiban, dan keutuhan NKRI, juga terkait erat dengan kesejahteraan masyarakat di daerah perbatasan. Secara garis besar, isu-isu yang muncul seputar wilayah perbatasan negara dapat dibagi ke dalam dua bagian. Pertama, penentuan batas-batas negara secara fisik dan pengamanannya; Kedua, pengelolaan pembangunan wilayah perbatasan negara.

Akhir-akhir ini, perhatian berbagai pihak terhadap eksistensi daerah perbatasan cukup meningkat. Hal demikian dapat dilihat dari berbagai kajian tentang wilayah perbatasan

\footnotetext{
Drs. Haris Faozan, M.Si adalah Staf Pengajar STIA LAN; Peneliti Madya pada Pusat Kajian Kinerja Kelembagaan, Kedeputian Kajian Kinerja Kelembagaan dan Sumber Daya Aparatur, Lembaga Administrasi Negara, Jakarta.
} 
yang dilakukan oleh pihak-pihak terkait dan/atau mempunyai perhatian terhadap wilayahwilayah perbatasan, seperti Lembaga Ilmu Pengetahuan Indonesia, Departemen Pertahanan, dan Forum Komunikasi Kelitbangan.

Secara konsep dan kebijakan, permasalahan-permasalahan yang muncul di wilayahwilayah perbatasan tidak bisa ditangani secara single actor oleh Pemerintah Daerah atau Pemerintah Pusat an sich. Setidak-tidaknya keterlibatan pihak-pihak lain -seperti TNI, POLRI, Kejaksaan Agung, Departemen Hukum dan HAM, Departemen Luar Negeri, Departemen Dalam Negeri dan lain-lain - dalam konteks tersebut intensitasnya sangat diharapkan. Hal demikian menjadi lebih krusial manakala wilayah-wilayah perbatasan dimaksud dalam kondisi konflik dan/atau rawan konflik.

Hingga saat ini urusan-urusan di wilayah-wilayah perbatasan pada umunya masih "ditangani" oleh Pemerintah Pusat. Selain sifatnya masih parsial dan kurang terkoordinasi, kinerja yang dicapai juga belum menggembirakan. Dengan melihat kondisi tersebut maka sangatlah perlu dan penting apabila kelembagaan Pemerintah Daerah perbatasan menjadi priority agenda. Hal demikian patut menjadi perhatian Pemerintah Pusat untuk memberikan jalan keluar melalui penguatan kapasitas kelembagaan Pemerintah Daerah pada wilayahwilayah perbatasan. Solusi seperti itu akan memberikan dampak positif bagi perkembangan wilayah-wilayah perbatasan secara umum.

Sementara ini hasil kajian mendalam mengenai kelembagaan Pemerintah Daerah di wilayah perbatasan termasuk langka. Kajian kelembagaan yang dijumpai lebih banyak terkait dengan kelembagaan Pemerintah Pusat, meskipun jumlahnya tidak banyak. Terdapat beberapa hal yang menjadi constraint mengapa kajian tentang kelembagaan Pemerintah Pusat dan Daerah di wilayah perbatasan langka. Beberapa penyebab yang dapat dipaparkan diantaranya adalah faktor keamanan, jarak tempuh lokasi dan biaya yang dibutuhkan dalam proses pengkajian.

Pada esensinya makalah ini mengangkat pentingnya penguatan kapasitas kelembagaan Pemerintah Daerah dalam pengelolaan daerah perbatasan. Isi makalah akan diawali dengan bahasan tentang permasalahan umum pengelolaan wilayah perbatasan. Selanjutnya dideskripsikan agenda RPJM-Nasional dalam penanganan wilayah perbatasan negara. Terakhir dibahas mengenai konsep penguatan kapasitas kelembagaan Pemerintah Daerah dalam pengelolaan daerah perbatasan.

\section{Wilayah Perbatasan Indonesia dan Permasalahan Pengelolaannya}

Wilayah perbatasan Indonesia meliputi darat, laut dan udara. Batas wilayah Indonesia di darat berada di Kalimantan yang berbatasan dengan Malaysia, di Papua berbatasan dengan Papua Nugini, dan di Nusa Tenggara Timur berbatasan dengan Timor Leste. Sementara itu, wilayah laut Indonesia berbatasan dengan 10 negara tetangga, yaitu Philipina, India, Vietnam, Malaysia, Thailand, Singapura, Papua Nugini, Australia, Palau, dan Timor Leste.

Secara umum pembangunan di wilayah-wilayah perbatasan tersebut jauh tertinggal dibandingan dengan pembangunan di wilayah-wilayah lainnya. Berdasarkan kondisi seperti itu, banyak pihak menilai bahwa Pemerintah Pusat dan bahkan Pemerintah Daerah tidak memiliki keinginan kuat untuk mengembangkan wilayah-wilayah perbatasan (Mawardi, 2006; Marsetio, 2005; Sudarisman, 2005 ${ }^{4}$; Putro; 2005 ). Terkait dengan penyelenggaraan

4 Pernyataan Victor Sudarisman pada Debat Publik "Menyikapi Berbagai Persoalan Di Wilayah Perbatasan" yang diselenggarakan oleh Himpunan Masyarakat Peduli Transmigrasi Indonesia, tanggal 29 Juni 2005 bertempat di Jakarta Media Centre, Jalan Kebon Sirih No. 32-34 Jakarta Pusat, dalam http://www.nakertrans.go.id/newsdetail.php?id=219 
otonomi daerah sebagaimana tertuang di dalam UU No. 32 Tahun 2004, pihak Pemerintah Daerah sepatutnya menangkap peluang tersebut dengan baik. Namun demikian, menurut pengakuan dan penilaian berbagai pihak, Pemerintah Daerah setengah hati untuk melaksanakan pembangunan di wilayah perbatasan. Hal demikian selain disebabkan oleh belum jelasnya kewenangan Pemerintah Daerah dalam pengelolaan pengembangan wilayah perbatasan, juga belum jelasnnya batas-batas wilayah antar negara.

Terkait dengan batas wilayah laut, Marsetio (2005) memerinci permasalahan yang berkembang, yaitu belum ditetapkannya perbatasan wilayah dengan negara tetangga, belum ditetapkannya batas wilayah antar daerah propinsi/kabupaten/kota, pengelolaan wilayah perbatasan laut masih sektoral, dan pembinaan masyarakat perbatasan termarjinalkan. Secara lebih jelas dan lengkap, Kementerian Perencanaan Pembangunan Nasional/Bappenas (2004) mengelompokkan permasalahan kawasan perbatasan (darat dan laut) ke dalam 6 aspek yaitu kebijakan, ekonomi dan social budaya, pertahanan dan keamanan, pengelolaan sumber daya alam, kelembagaan dan kewenangan pengelolaan, serta kerjasama antar negara.

Gambaran di atas memberikan pandangan bahwa pengelolaan wilayah perbatasan selain membutuhkan keterlibatan Pemerintah Pusat secara sinergis, keterlibatan sinergisme Pemerintah Daerah serta dan para stakeholder juga sangat diperlukan. Pemerintah Daerah selaku penyelenggara pemerintahan dan pembangunan di daerah otonom, sudah saatnya mengambil peran secara lebih intensif dalam pengeloaan wilayah perbatasan. Sembari menunggu terbitnya undang-undang tentang perbatasan negara, Pemerintah Daerah perlu menata kembali kelembagaan atau unit kerja yang diberi kepercayaan untuk mengelola daerah perbatasan.

Beberapa hasil kajian dan forum diskusi kelitbangan menunjukkan (Lembaga Administrasi Negara, 2004; Forum Komunikasi Kelitbangan, 2005) bahwa:

1. Kiprah pemerintah pusat dalam penanganan wilayah perbatasan masih jauh dari yang diharapkan. Penangannya bersifat sektoral dan tidak terkoordinir dengan baik, sehingga pengembangan wilayah perbatasan jauh tertinggal dengan wilayah-wilayah lain.

2. Penanganan batas negara (darat dan laut) belum tuntas, sehingga menimbulkan kesulitan bagi daerah dalam pengeloaan wilayah perbatasan.

3. Pelimpahan kewenangan kepada Pemerintah Daerah dalam penanganan wilayah perbatasan tidak jelas, sehingga Pemerintah Daerah merasa sulit untuk mengambil langkah-langkah pengembangan wilayah perbatasan.

Hasil Workshop Pembangunan Daerah Perbatasan Indonesia, yang diselenggarakan LIPI pada tanggal 22-23 Oktober 2002 di Jakarta cukup memberikan gambaran bagaimana pemerintah daerah mengembangkan wilayah perbatasan. Hasil workshop tersebut secara ringkas adalah sebagai berikut:

- Gubernur Kalimantan Timur menjelaskan bahwa pembangunan di wilayah perbatasan Kalimantan Timur adalah untuk membangun kawasan perbatasan sebagai pusat pertumbuhan baru yang berdaya tahan dan berdaya saing, berbasiskan pada sumberdaya alam lestari dan sumberdaya manusia yang handal. Sasaran yang ingin dicapai dalam konteks tersebut adalah terciptanya kawasan yang memiliki keunggulan daya saing melalui upaya pemanfaatan dan penguatan kapabilitas yang dimiliki; terwujudnya kawasan perbatasan sebagai pusat pertumbuhan yang eksis dalam interaksi pasar global; dan terwujudnya kawasan perbatasan yang mampu mendorong pertumbuhan dan

Suwarno Putro pada Debat Publik "Menyikapi Berbagai Persoalan Di Wilayah Perbatasan" yang diselenggarakan oleh Himpunan Masyarakat Peduli Transmigrasi Indonesia, tanggal 29 Juni 2005 bertempat di Jakarta Media Centre, Jalan Kebon Sirih No. 32-34 Jakarta Pusat, dalam http://www.nakertrans.go.id/newsdetail.php?id=219 
perkembangan investasi untuk mendukung peningkatan perekonomian daerah dan nasional.

- Bupati Nunukan menjelaskan bahwa kawasan perbatasan dibedakan menjadi dua, yaitu kawasan perbatasan dengan pertumbuhan cepat dan kawasan terbelakang (terisolir). Terkait dengan pembangunan pada dua kawasan tersebut, Bupati Nunukan memandang perlu untuk melakukan penguatan kapasitas kelembagaan, mempertimbangkan sejumlah persoalan yang dihadapi wilayah perbatasan. Dalam kesempatan tersebut Bupati Nunukan menyarankan agar dilakukan peninjauan kembali terhadap kebijakan status kewenangan pengelolaan wilayah perbatasan dikaitkan dengan pelaksanaan otonomi dan desentralisasi daerah.

- Bupati Sintang Kalimantan Barat menyampaikan bahwa permaslahan yang dihadapi dalam mengelola wilayah perbatasan yaitu luasnya kawasan perbatasan dan pedalaman yang dimiliki, terbatasnya saluran informasi yang dimiliki, kecilnya dana pembangunan wilayah perbatasan, sulitnya hubungan transportasi, sulitnya memobilisasi peralatan untuk pengembangan infrastruktur dan pemasaran hasil pertanian dan perkebunan, terdapatnya aktivitas ekonomi illegal, kerapnya terjadi pemindahan patok batas dan pencurian kekayaan alam, dan belum adanya kejelasan kewenangan pemerintah daerah dalam penanganan daerah perbatasan. Terkait dengan berbagai permasalahan tersebut maka strategi penanganan dan kebijakan wilayah perbatasan harus bersifat holistic. Program pembangunan wilayah perbatasan di kabupaten Sintang terdiri dari 4 aspek pokok, yaitu membangun kesejahteraan rakyat dan ketahanan budaya masyarakat perbatasan, meningkatkan kapasitas daerah melalui penataan ruang, pembangunan sarana trasportasi, pembangunan perumahan, dan pengembangan kapasitas lembaga pengelola pembangunan perbatasan, percepatan pembangunan ekonomi kerakyatan, dan pegakan supremasi hukum dan pemerintahan yang baik.

- Aparat Kabupaten Belu mengemukakan tentang potensi dan kendala Kabupaten Belu sebagai daerah yang berbatasan langsung dengan negara Timor Leste. Potensi yang dimiliki Kabupaten Belu adalah peternakan, pertambangan, kehutanan, pertanian pangan, wisata bahari, wisata budaya dan wisata alam. Sementara itu permasalahan yang terkait dengan wilayah perbatasan terbagi menjadi dua, yaitu permasalahan umum dan permasalahan khusus. Permasalahan umum mencakup lemahnya dukungan lembaga keuangan, rendahnya kualitas pendidikan, tidak memadainya jumlah tenaga kesehatan, dan tidak mendukungnya sarana dan prasarana penunjang kegiatan pembangunan. Permasalahan khusus antara lain terkait dengan tidak kondusifnya kondisi kamtibmas, munculnya pasar gelap di wilayah perbatasan, dan pengrusakan hutan lindung. Sehubungan dengan kedua permasalahan tersebut kebijakan yang direkomendasikan adalah prioritas peningkatan jalan raya yang mempunyai akses langsung ke Timor Leste dan peningkatan irigasi pada desa-desa di wilayah perbatasan.

- Aparat Kabupaten Jayapura menyampaikan beberapa hal yang menjadi kendala pembangunan daerah perbatasan antara Kabupaten Jayapura dengan PNG. Jalan penghubung untuk transportasi antar daerah perbatasan masih mengalami kesulitan, sehingga pemasaran hasil produksi masyarakat ke kota Jayapura mengalami kesulitan. Dalam kesempatan tersebut diusulkan agar distrik-distrik di wilayah perbatasan perlu terus dibenahi melalui dana alokasi khusus baik dari Daerah maupun Pusat karena urusan wilayah perbatasan merupakan urusan Pemerintah Pusat.

- Bupati Kabupaten Merauke menyatakan bahwa kabupaten Merauke memiliki banyak potensi diantaranya yaitu tanaman pangan, perkebunan kelapa sawit, peternakan, perikanan, kehutanan, wisata alam, wisata budaya, dan wisata sejarah. Sementara itu permasalahan di wilayah perbatasan yang belum dapat diatasi secara tuntas adalah 
gangguan keamanan dan pelintas batas ke PNG yang dilakukan masyarakat Kabupaten Merauke.

Menyimak uraian di atas, maka dapat disimpulkan bahwa Pemerintah Daerah yang mengelola wilayah perbatasan berkeinginan untuk mewujudkan kesejahteranaan, kemanan dan ketertiban. Namun demikian untuk merealisasikan hal dimaksud, kontribusi dari Pemerintah Pusat tetap dibutuhkan baik dalam konteks otonomi daerah maupun yang terkait dengan hubungan bilateral antar dua negara, yaitu Indonesia dengan setiap negara tetangga yang berbatasan dengan daerah tertentu.

\section{Agenda RPJM Nasional Dalam Penanganan Wilayah Perbatasan}

Pengelolaan wilayah perbatasan di Indonesia sampai saat ini masih dirasa tidak optimal. Kewenangan pengelolaan wilayah perbatasan belum memiliki peta yang jelas berdasarkan pembagian kewenangannnya, baik bagi Pemerintah Pusat maupun Pemerintah Daerah. Ketidakjelasan pembagian kewenangan ini mungkin yang menjadi issue mengapa persoalan pengelolaan daerah perbatasan tidak kunjung tertangani dengan baik. Selain dari pada itu, sistem dan prosedur pengelolaannya pun belum dirumuskan secara jelas, sehingga penanganan daerah perbatasan dirasakan parsial dan kurang terkoordinir.

Selanjutnya, hal ikhwal wilayah perbatasan yang mencakup permasalahan, sasaran, arah kebijakan pembangunan, dan program pengembangannya dipaparkan di dalam Perpres No. 7 Tahun 2005 tentang Rencana Pembangunan Jangka Menengah Nasional (RPJMNasional). Dengan lahirnya Perpres No. 7 Tahun 2005, hal ini memberikan indikasi bahwa pemerintah Indonesia pada dasarnya concern terhadap pembangunan wilayah perbatasan. Di dalam Perpres No. 7 Tahun 2005, pembangunan wilayah perbatasan tertuang pada Bab

Pengurangan Ketimpangan Pembangunan Daerah. Permasalahan yang diangkat terkait dengan wilayah perbatasan, adalah sebagai berikut:

"...[N]amun di beberapa wilayah perbatasan terjadi kesenjangan pembangunan yang cukup besar dengan negara tetangga yang dikawatirkan dalam jangka panjang akan menimbulkan berbagai kerawanan. Untuk wilayah perbatasan (khususnya perbatasan darat) disamping masalah rendahnya dana pembangunan, penyebab utama ketertinggalan adalah akibat dari arah kebijakan pembangunan kewilayahan yang selama ini cenderung berorientasi 'inward looking' sehingga seolah-olah kawasan perbatasan hanya menjadi halaman belakang dari pembangunan kita. Sementara itu pulau-pulau kecil yang ada di Indonesia sulit berkembang terutama karena lokasinya sangat terisolir dan sulit dijangkau. Diantaranya banyak yang tidak berpenghuni atau sangat sedikit jumlah penduduknya, serta belum tersentuh oleh pelayanan dasar dari pemerintah seperti sekolah, puskesmas, dan lain-lain."

Sasaran dari pengurangan ketimpangan pembangunan daerah (terkait dengan wilayah perbatasan) adalah:

- Terwujudnya peningkatan kesejahteraan masyarakat di seluruh wilayah dan berkurangnya kesenjangan pembangunan antar wilayah;

- Terwujudnya percepatan pengembangan wilayah serta peningkatan daya saing kawasan dan produk-produk unggulan.

Selanjutnya, arah kebijakan pengurangan ketimpangan pembanguan daerah (terkait dengan wilayah perbatasan) diarahkan untuk mengembangkan wilayah-wilayah perbatasan dengan mengubah arah kebijakan pembangunan wilayah perbatasan yang selama ini 
cenderung berorientasi inward looking menjadi outward looking, sehingga kawasan tersebut dapat dimanfaatkan sebagai pintu gerbang aktivitas ekonomi dan perdagangan dengan negara tetangga. Disamping itu, selain menggunakan pendekatan yang bersifat keamanan (security approach), juga diperlukan pendekatan kesejahteraan (prosperity approach).

Langkah-langkah yang akan ditempuh dalam pengurangan ketimpangan pembangunan daerah (terkait dengan wilayah perbatasan), dijabarkan ke dalam Program Pengembangan Wilayah Perbatasan. Program ini ditujukan untuk menjaga keutuhan wilayah NKRI melalui penetapan hak kedaulatan NKRI yang dijamin oleh hukum internasional; meningkatkan kesejahteraan masyarakat setempat dengan menggali potensi ekonomi, social dan budaya serta potensi lokasi perbatasan; dan menjadikan wilayah perbatasan sebagai halaman depan negara sehingga tercapai hubungan yang harmonis antara negara RI dengan negara tetangga dan antara masyarakat Indonesia dengan masyarakat negara tetangga. Kegiatan pokok yang akan dilakukan adalah:

1. Fasilitasi Pemerintah Daerah untuk mengembangkan wilayah perbatasan antar negara sehingga wilayah perbatasan dapat menjadi beranda depan negara, yang baik kondisi fisik maupun kehidupan masyarakatnya tidak sangat jauh berbeda dengan yang ada di negara tetangga;

2. Deklarasi serta penetapan garis perbatasan antar negara dengan tanda-tanda batas yang jelas;

3. Pengamanan wilayah perbatasan dari kegiatan illegal dan fasilitasi pergerakan barang dan orang secara sah dan mudah;

4. Pengembangan wilayah perbatasan sebagai pusat pertumbuhan ekonomi berbasis sumber daya alam lokal melalui pengembangan sektor-sektor unggulan;

5. Peningkatan kualitas sumber daya manusia khusunya dalam bidang kesehatan dan pendidikan;

6. Peningkatan kapasitas kelembagaan pemerintah daerah dan masyarakat;

7. Peningkatan wawasan kebangsaan masyarakat; serta

8. Penegakan supremasi hukum serta aturan perundang-undangan terhadap setiap pelanggaran yang terjadi di wilayah perbatasan.

Terkait dengan amanat Perpres No. 7 Tahun 2005 kepada Pemerintah Daerah, tugas Pemerintah Pusat adalah melakukan fasilitasi kepada Pemerintah Daerah agar mampu melaksanakan amanat-amanat tersebut. Tetapi sayangnya, walaupun pemerintah telah menetapkan arah kebijakan dan program pembangunan daerah perbatasan sebagaimana tertuang di dalam kebijakan RPJM-Nasional, namun kenyataannya greget implementasi kebijakan tersebut belum terasa. Hal ini didasarkan pula pada pengalaman selama ini, dimana Pemerintah Pusat belum mampu secara optimal melaksanakan tugas dan fungsinya dalam memberikan fasilitasi dan pembinaan kepada Pemerintah Daerah dalam penyelenggaraan kebijakan desentralisasi.

Dalam pada itu, merujuk pada Perpres No. 7 Tahun 2005 tentang RPJM-Nasional khususnya mengenai wilayah perbatasan, tampaknya peran yang perlu dilakukan oleh Pemerintah Daerah sudah cukup jelas. Pemerintah Daerah diamanatkan untuk melakukan penguatan kapasitas kelembagaan Pemerintah Daerah dan masyarakat dalam rangka pengembangan wilayah perbatasan sebagai pusat pertumbuhan ekonomi berbasis sumber daya alam lokal melalui pengembangan sektor-sektor unggulan. Selain itu Pemerintah Daerah juga diamanatkan untuk mengembangkan wilayah perbatasan antar negara agar menjadi 
beranda depan negara, yang baik kondisi fisik maupun kehidupan masyarakatnya tidak sangat jauh berbeda dengan yang ada di negara tetangga.

Namun demikian hal itupun merupakan permasalahan yang belum terjawab. Sebagaimana disampaikan oleh Sapto Supono (2006) dalam Pertemuan Forum Komunikasi Kelitbangan (FKK) Departemen, Kementerian, dan LPND di LAN Jakarta yang menyatakan bahwa kebijakan Pemerintah Kabupaten dan Provinsi yang dituangkan di dalam APBD belum banyak memperhatikan masalah-masalah perbatasan mengingat besarnya kendalakendala yang ditemui.

\section{Perlunya Penguatan Kapasitas Kelembagaan Pemerintah Daerah Dalam Pengembangan Daerah Perbatasan}

Tuntutan masyarakat pada peningkatan kualitas pembangunan serta kualitas pelayanan yang diselenggarakan Pemerintah Daerah pada semua sektor terus datang bertubitubi. Hal demikian menunjukkan bahwa tantangan yang dihadapi pemerintahan daerah dewasa ini semakin menguat. Sangat disadari bahwa tantangan demikian bukanlah hal mudah. Selain harus dikelola secara sinergis, konsisten, simultan, dan berkesinambungan, otonomi daerah semestinya dikelola secara memadai dengan mencermati akar permasalahannya dan kemudian dilanjutkan dengan pengaturan melalui kebijakan-kebijakan yang konsisten dan tidak bertentangan dengan sebagian besar aspirasi masyarakat dan stakeholder.

Penguatan kapasitas Pemerintah Daerah di wilayah perbatasan menjadi agenda kegiatan pokok pemerintah Indonesia sebagaimana tertuang di dalam RPJM 2005-2009. Peningatan kapasitas Pemerintah Daerah dalam konteks tersebut tentunya bukan sekedar membentuk unit kerja tertentu yang bertugas mengelola wilayah perbatasan. Penguatan kapasitas Pemerintah Daerah dimaksud merupakan penguatan kapasitas kelembagaan Pemerintah Daerah secara holistic dan komprehensif yang bertugas mengelala wilayah perbatasan di daerah otonom.

Patut dipahami bersama bahwa penguatan kapasitas merupakan suatu proses tiada henti. Hal demikian sama halnya dengan penguatan kapasitas Kelembagaan Pemerintah Daerah pengelola daerah perbatasan, prosesnya perlu dilakukan secara bertahap dan berkesinambungan dalam rangka mencapai efisiensi dan efektivitas kelembagaan secara optimal dari waktu ke waktu. Proses penguatan kapasitas kelembagaan Pemerintah Daerah pengelola daerah perbatasan dapat pula diartikan sebagai pendorong reformasi birokrasi pemerintah lokal dalam kerangka pencapaian visi dan misi yang dicanangkan.

Proses awal penguatan kapasitas kelembagaan Pemerintah Daerah pengelola daerah perbatasan diorientasikan kepada beberapa aspek mendasar dan krusial yang dapat digunakan sebagai dasar proses penguatan kapasitas kelembagaan Pemerintah Daerah pengelola daerah perbatasan pada masa-masa yang akan datang. Proses awal ini perlu diperhatikan agar skenario penguatan kapasitas kelembagaan Pemerintah Daerah pengelola daerah perbatasan bukan semata-mata tambal sulam melainkan memiliki arah dan tujuan yang jelas. Oleh karenanya, dalam kerangka tersebut sangatlah jelas bahwa penguatan kapasitas kelembagaan Pemerintah Daerah harus segera dirancang dan dibangun secara komprehensif dan terpadu. 
Penguatan kapasitas kelembagaan Pemerintah Daerah dapat diartikan sebagai upaya membangun organisasi, sistem-sistem, kemitraan, orang-orang dan proses-proses secara benar untuk menjalankan agenda atau rencana tertentu. Penguatan kapasitas kelembagaan Pemerintah Daerah oleh karenanya berkaitan dengan individual capability development, organizational capacity building, dan institutional capacity building. Pengertian penguatan kapasitas tersebut memberikan gambaran bahwasanya terdapat banyak hal yang harus diperhatikan dan dicermati secara jeli agar penguatan kapasitas dapat membuahkan hasil nyata, bermanfaat, dan menimbulkan dampak positif. Dalam pada itu penguatan kapasitas kelembagaan Pemerintah Daerah diarahkan bertujuan untuk:

1. Mengembangkan keterampilan dan kompetensi individual sehingga masing-masing individu mampu melaksanakan tugas dan tanggung jawab yang diembannya.

2. Mengembangkan para pegawai, budaya, sistem dan proses-proses ke dalam otoritas/kewenangan unit-unit organisasi dalam rangka mencapai tujuan unit-unit organisasi masing-masing.

3. Mengembangkan dan menguatkan jalinan keluar (development and strengthening of external links) dalam rangka menumbuhkembangkan kemitraan secara intensif, ekstensif, dan solid.

Dalam kaitannya dengan penilaian kapasitas di dalam organisasi-organisasi, penilaian yang perlu dilakukan sebelum melakukan penguatan kapasitas kelembagaan adalah tertuju pada wilayah-wilayah utama berikut:

1. Keuangan: apakah modal dan/atau revenue funding tersedia pada saat ini dan pada masa yang akan datang untuk mencapai peningkatan-peningkatan yang dikehendaki?

2. Sistem dan proses: apakah metode kerja, disain jabatan dan sistem komunikasi, pengambilan keputusan dan penghargaan berdampak positif kepada kapabilitas individu? Apakah sistem dan proses tersebut mampu memfasilitasi peningkatan berkelanjutan?

3. Orang: apakah para pucuk pimpinan memiliki cukup staff (pimpinan satu atau dua tingkat di bawahnya) untuk melaksanakan pekerjaan atau apakah para pucuk pimpinan memiliki kecukupan kemampuan untuk memperoleh sumberdaya tambahan jika diperlukan?

4. Skills: berkaitan dengan kemampuan teknis staff atau mitra yang ada saat ini, misalnya, apakah mereka memiliki keterampilan manajemen proyek secara memadai?

5. Knowledge: apakah pucuk pimpinan dan bawahannya memiliki pemahaman yang mencukupi mengenai bagaimana cara mengelola perubahan (managing change) dan bagaimana cara meningkatkan kualitas pelayanan?

6. Perilaku: apakah perilaku pucuk pimpinan memfasilitasi dan memungkinkan peningkatan? Apakah para pimpinan menengah dan stafnya bertindak sesuai dengan nilai dan tujuan yang dinyatakan pimpinan puncak?

Sebagaimana diuraikan pada bagian sebelumnya bahwa dimensi pengembangan kapasitas mencakup individu, organisasi/unit kerja dan kelembagaan/institusi. Sehubungan dengan hal itu, maka kesenjangan kapasitas kelembagaan Pemerintah Daerah saat ini (current gaps) harus dicermati. Kesenjangan-kesenjangan yang diuraikan menyangkut hal-hal stratejik yang secara signifikan akan berdampak potensial pada kinerja kelembagaan Pemerintah Daerah itu sendiri. 
Pada umumnya kesenjangan kapasitas kelembagaan - dan hal ini dianalogkan juga pada pemerintah provinsi dan kabupaten/kota di Indonesia - dapat dipilah ke dalam tingkatan sebagai berikut:

1. Manajemen Organisasional/Stratejik.

Kesenjangan pada level ini sangat terkait dengan kepemilikan kompetensi kepemimpinan (leadership competencies). Meskipun pada 2 level yang lain -manajemen operasional dan pelayanan-, kepemilikan kompetensi kepemimpinan juga diperlukan, tetapi pada tataran manajemen stratejik, kompetensi tersebut sangat diutamakan terutama dalam penataan kelembagaan atau pengembangan organisasi (organization development), membangun budaya organisasi (organization culture) manajemen perubahan (change management) yang mengarah pada peningkatan kinerja instansional dimana pada gilirannya akan menjadi pengungkit kinerja daerah. Hal tersebut dirasakan semakin penting karena keputusan-keputusan dan tindakan stratejik berada pada level ini.

Selain itu, dewasa ini kepamampuan membangun jejaring atau kemitraan stratejik (building strategic network/partnership) pada skala yang lebih luas (nasional maupun internasional) sudah merupakan kebutuhan. Hal ini dikarenakan pemerintah daerah pada kondisi semakin sulit untuk mengatasi segala permasalahan pemerintahan, pembangunan dan pelayanan umum secara sendiri tanpa bantuan pihak ketiga.

2. Manajemen Operasional.

Kesenjangan pada level manajemen operasional terkait dengan budaya kerja (work culture) dan manajemen kinerja (performance management), sistem dan proses kerja (work system and processes). Pada level ini, keberadaan kapasitas pimpinan pada lini tengah (middle and lower managers) memegang peran kunci untuk mengejawantahkan berbagai rencana stratejik yang telah dicanangkan. Pengalaman selama ini menunjukkan bahwa tidak tercapainya kinerja pemerintah daerah secara maksimal cenderung disebabkan oleh implementasi strategi yang tidak memadai, baik dalam kaitannya dengan program, anggaran, maupun prosedur yang dicanangkan.

Banyak faktor yang menjadi penyebab tidak optimalnya kinerja pada tingkat manajemen operasional, diantaranya yaitu:

- Kurang memadainya budaya kerja para pimpinan pada level tersebut.

- Belum tersedianya sistem manajemen berbasis kinerja (performance-based management system)

- Kurang memadainya pengetahuan tentang change management.

- Belum terbangunnya standard operating procedures (SOP) yang baku pada setiap kegiatan yang dilaksanakan.

3. Manajemen Pelayanan.

Pelayanan dalam hal ini terkait dengan ranah pelayanan yang berkontribusi secara langsung terhadap efektivitas institusi, misalnya kapasitas teknologi informasi, sumber daya manusia, pengelolaan fasilitas, pelayanan hukum dan keuangan. Dalam kaitannya dengan kapasitas pelayanan maka kesenjangan yang ada terkait dengan ketersediaan 
layanan, pengetahuan dan keterampilan professional dan pengetahuan keterampilan pimpinan pada umumnya (knowledge and skills of managers generally).

Merujuk pada hasil penelitian pengembangan kapasitas pemerintahan daerah di negara lain adalah hasil penelitian William Ramphele (2003). Ramphele mengidentifikasi beberapa keterbatasan pengembangan kapasitas pemerintah daerah-daerah di Afrika Selatan, sebagai berikut:

- Tidak memadainya infrastruktur dan penataan kelembagaan pemerintah kabupaten. Meskipun di beberapa daerah tersedia infrastruktur yang memadai, tetapi pemerintah daerah belum mampu mengoptimalkan sistem operasi untuk menghasilkan pelayanan masyarakat yang lebih baik. Hal demikian sangat tergantung kepada anggaran yang ketertersediaannya sangat terbatas. Kondisi demikian diperkeruh dengan hubungan antar struktur pemerintah daerah yang kurang solid, sehingga keberadaan mereka tidak pada kondisi sinergis dan cenderung mementingkan unit masing-masing.

- Lemahnya dalam mengelola kapasitas yang tersedia. Sebagian besar pemerintah daerah belum mampu membangun sistem dan proses dukungan internal pemerintah kabupaten secara memadai. Hal ini berdampak pada belum memadainya kinerja internal pemerintah kabupaten.

- Kurangnya motivasi untuk membangun kapasitas pemerintah kabupaten. Meskipun otonomi daerah bertujuan untuk memberikan kapasitas yang lebih besar kepada pemerintah daerah untuk mengelola pembangunan secara lebih efektif, tetapi hal tersebut tidak bisa diwujudkan karena lemahnya kapasitas pemerintah kabupaten itu sendiri.

Dari uraian di atas secara esensi dapat diketahui bahwa permasalahan pengembangan kapasitas kelembagaan Pemerintah Daerah secara umum memiliki kesamaan. Permasalahan-permasalahan tersebut dapat diperinci sebagai berikut:

1. Belum memadainya penataan kelembagaan organisasi pemerintah daerah (organization development) berdasarkan kaidah struktur dan disain organisasi (structure and design).

2. Belum terbangunnya sistem manajemen kinerja (performance management system) pemerintah daerah, termasuk juga manajemen sumber daya manusia berbasis pada kompetensi (competence-based human resource management) dan sistem pengukuran kinerja (performance measurement system).

3. Belum terwujudnya budaya organisasi (organization culture) yang sensitif terhadap tuntutan lingkungan (internal maupun eksternal).

4. Belum terbangunnya standar pelayanan umum (public services standard), terutama pelayanan dasar, yang dirancang secara komprehensif dan terpadu.

5. Belum memadainya pengetahuan tentang manajemen perubahan (change management) dan bagaimana mengantisipasi perubahan tersebut dalam praktek pekerjaan sehari-hari.

6. Belum memadainya skills dalam menjalankan tugas dan tanggungjawab yang diemban, terutama dalam kaitannya dengan pelayanan, baik pelayanan kepada masyarakat pada umumnya maupun pelayanan dalam skala internal pemerintah daerah.

7. Belum memadainya infrastruktur dan fasilitas pendukung kinerja, terutama yang berkaitan dengan teknologi komunikasi dan informasi (information and communication technology). 
Merujuk uraian sebelumnya, maka pada dasarnya penguatan kapasitas Kelembagaan Pemerintah Daerah pengelola daerah perbatasan mencakup penguatan kapasitas 3 (tiga) unsur kelembagaan yaitu organisasi, ketatalaksanaan, dan SDM Aparatur. Ketiga unsur kelembagaan tersebut merupakan satu kesatuan sistem yang komprehensif dan holistik, sehinggga penguatan kapasitasnya perlu dilakukan secara terintegrasi dan terpadu.

Apabila dicermati, pokok permasalahan belum optimalnya kinerja otonomi daerah bermuara pada lemahnya strategi pengembangan kelembagaan organisasi pemerintahan daerah. Dengan mencermati perubahan yang terjadi, strategi pengembangan organisasi pemerintahan daerah (local government organization development strategy) sepatutnya ditujukan pada pemenuhan sinergisme tiga strategi utama, yaitu structural strategy, behavior strategy, dan technical strategy sehingga pemerintahan daerah mampu mewujudkan kinerja otonomi daerah secara maksimal.

The Structural Strategy menggunakan pendekatan disain organisasi (organization design), dalam mana struktur organisasi dan disain semestinya diselaraskan kembali dengan: (1) fungsi-fungsi organisasi (2) Prinsip-prinsip pengorganisasian (3) Peraturan Perundangan tentang Penataan Organisasi Perangkat Daerah. Selain itu para pegawai Sekretariat Daerah, Dinas Daerah, dan Lembaga Teknis Daerah dan unit kerja di dalamnya sebaiknya diselaraskan pada optimasi sumberdaya. Misalnya, hierarkhi organisasi semestinya dibuat datar dan pengambilan keputusan ditempatkan lebih dekat pada pelaksana tindakan. Esensi penyelerasan struktur organisasi dengan disain organisasi adalah untuk mewujudkan new relationship.

Sementara itu di ranah organisasi Pemerintahan Daerah, pendekatan disain organisasi belum dikonsistensikan secara maksimal dengan visi, misi, dan tujuan organisasi. Hal ini dapat dicermati dari kecenderungan sebagian besar pemerintahan daerah (Propinsi, Kabupaten/Kota) untuk memperbanyak posisi jabatan strukturalnya tanpa mempertimbangkan korelasi pencapaian kinerjanya. Dengan hierarkhi yang semakin tinggi, secara langsung maupun tidak langsung akan berdampak terhadap semakin banyaknya waktu yang dibutuhkan dalam pengambilan keputusan maupun dalam konteks hubungan antar hierarkhi (inter-hierarchies relationship).

Behavior Strategy ini lebih menekankan bagaimana mengembangkan budaya kerja organisasi. Pengembangan budaya tersebut dimulai dari pembelajaran pegawai yang pada gilirannya akan membawa perubahan organisasi ke arah yang lebih baik. Dalam konteks ini, pembelajaran pegawai semestinya mengandung pemerolehan knowledge, skills and new attitudes yang akan mengarah pada perilaku-perilaku yang baru (new behaviors). New behaviors inilah yang kemudian akan mengarah pada peningkatan kualitas dan kinerja individu, kelompok, dan bahkan organisasi.

Sebaliknya, pendekatan pelatihan dan pengembangan pegawai pemerintahan daerah belum diorientasikan secara memadai pada pemerolehan dan pengembangan knowledge, skills and attitudes semacam itu. Hal ini bisa dirasakan karena implemetasi pelatihan dan 
pengembangan dilakukan secara parsial, tidak konsisten, dan jauh selaras dari pencapaian visi, misi, dan tujuan organisasi.

The Technical Strategy menggunakan pendekatan peningkatan berkelanjutan (continuous improvement approach). Pendekatan ini menekankan bahwa bidang-bidang yang berkaitan dengan fokus pada masyarakat, pemberian layanan, dukungan, dan kemitraan harus ditingkatkan. Selain itu pendekatan ini juga memandang pentingnya peningkatan (updated) teknologi dan diselaraskan (aligned) dengan proses-proses produksi dan pelayanan sehingga mampu bekerja secara efisien dan efektif.

Penyelarasan teknologi dengan proses produksi dan pelayanan di lingkungan pemerintahan daerah di negara-negara maju diejawantahkan dalam Electronic Government (e-Govt) atau Government On-Line (GOL). Diplikasikannya e-govt atau GOL dewasa ini merupakan upaya mewujudkan kualitas pelayanan kepada masyarakat dan stakeholders tanpa batas. Dengan peningkatan proses secara terus-menerus dan diselaraskan dengan penggunaan teknologi yang juga terus-menerus ditingkatkan, akan mengarah pada peningkatan kualitas dan kinerja.

Sementara itu di dalam organisasi pemerintahan daerah, technical strategy belum menjadi prioritas utama dalam strategi pengembangan organisasinya. Kondisi demikian dapat ditelusuri dari belum maksimalnya fokus pada masyarakat, pemberian layanan, dukungan, dan kemitraan. Lebih jauh lagi, penggunaan teknologi masih dianggap sebagai barang mewah, sehingga konsumsi teknologi seringkali menjadi terabaikan. Meskipun beberapa pemerintahan daerah di Indonesia telah mengebangkan website, namun demikian informasi yang tertuang maupun layanan di dalamnya belum mampu memenuhi harapan masyarakat dan stakeholders.

Berdasarkan uraian strategi pengembangan organisasi di atas, tampak jelas bahwa belum optimlanya perubahan kelembagaan pemerintahan di daerah bisa disebabkan oleh lemahnya strategi pengembangan organisasi pemerintahan daerah secara kolektif. Agregasi permasalahan yang semakin menumpuk dan berat, menimbulkan kesulitan dalam menemukan solusi praktis otonomi daerah di Indonesia. Dengan demikian jelas dibutuhkan hadirnya solusi tepat dan bijak yang mengarah pada penguatan kelembagaan pemerintahan daerah di era otonomi daerah dewasa ini.

\section{Penutup}

Daerah perbatasan sebagai bagian dari daerah otonom, keberadaan maju dan mundurnya dipengaruhi oleh perhatian Pemerintah Daerah itu sendiri meskipun hal ini juga tidak bisa lepas dari kontribusi Pemerintah Pusat. Sehubungan dengan hal itu, maka penguatan kapasitas kelembagaan Pemerintah Daerah dalam pengembangan daerah perbatasan perlu digalakkan. Hal demikian semakin penting manakala suatu daerah menjadi daerah otonom, dimana tujuan otonomi daerah itu sendiri adalah untuk meningkatkan 
kesejahteraan masyarakat, meningkatkan pelayanan umum, dan meningkatkan daya saing daerah. Dalam kerangka tersebut, diterapkan prinsip otonomi seluas-luasnya sehingga daerah diberikan kewenangan mengurus dan mengatur semua urusan pemerintahan berdasarkan ketentuan yang ditetapkan. Oleh karena itu, kini saatnya bagi Pemerintah Daerah yang memiliki daerah perbatasan melakukan penguatan kapasitas kelembagaannya sebagai bagian tidak terpisahkan peningkatkan kinerja otonomi daerah.

\section{Daftar Bacaan}

Forum Komunikasi Kelitbangan. Pertemuan Lanjutan Semiloka Penyerasian Program Litbang dalam Optimalisasi Wilayah Perbatasan, 2005, di Gedung Departemen Kelautan dan Perikanan, Jl. Mereka Timur 16 Jakarta Pusat, Tanggal 12 Juli.

Himpunan Masyarakat Peduli Transmigrasi Indonesia, 2005, Debat Publik, "Menyikapi Berbagai Persoalan Di Wilayah Perbatasan", tanggal 29 Juni 2005 bertempat di Jakarta Media Centre, Jalan Kebon Sirih No. 32-34 Jakarta Pusat, dalam http://www.nakertrans.go.id/newsdetail.php?id=219

Kementerian Perencanaan Pembangunan Nasional/BAPPENAS, 2004, Kawasan Perbatasan: Kebijakan dan Strategi Nasional Pengelolaan Kawasan Perbatasan Antar Negara di Indonesia, Jakarta.

Lembaga Administrasi Negara, 2004, Laporan Kajian Manajemen Wilayah Perbatasan, Jakarta, (Tidak dipublikasikan).

Lembaga Ilmu Pengetahuan Indonesia, Workshop Pembangunan Daerah Perbatasan Indonesia, tanggal 22-23 Oktober 2002 di Jakarta.

Marsetio, Kolonel Laut (P), MM., 2005, Pendayagunaan Wilayah Perbatasan Laut Guna Mendukung Pembangunan Nasional Dalam Rangka Persatuan Dan Kesatuan Bangsa, dalam http://www.tnial.mil.id/cakrad_cetak.php?id=343

Mawardi, Ikhwanuddin (Staf Ahli Menteri Negara Perencanaan Pembangunan Nasional/Bappenas Bidang Regional dan SDA), 2006, Penanganan Daerah Perbatasan Negara Dari Aspek Percepatan Pembangunan, Makalah disampaikan dalam Diskusi Terbatas Pusat Kajian Kinerja Kelembagaan LAN. Jakarta, 2 Maret.

Office of the Deputy Prime Minister (ODPM), Capacity Building in Local Governmentresearch on capacity building needs: Final Report, June 2003 dalam www.odpm.gov.uk/index.asp?id=1133945

Perpres No. 7 Tahun 2005 tentang Rencana Pembangunan Jangka Menengah Nasional (RPJM-Nasional)

Ramphele, William, 2003, Discussion paper on Local Government Capacity Building, Department of Provincial and Local Government. South Africa Government. Dalam DISCUSSION PAPER ON LOCAL GOVERNMENT www.environment.gov.za/HotIssues/2003jul24/

Supono, Sapto (Kepala Badan Penelitian dan Pengembangan, Departemen dalam Negeri). Pembangunan Wilayah Perbatasan Kalimantan Dalam Perspektif Administrasi pemerintahan. Makalah dalam Pertemuan Forum Komunikasi Kelitbangan Departemen, Kementerian dan LPND di Lembaga Administrasi Negara, Jakarta, 13 April 2006. 